\title{
Productive Characteristics and Reproductive Responses to Estrus Synchronization and Flushing in Abou-Delik Ewes Grazing in Arid Rangelands in Halaieb - Shalateen - Abouramad Triangle of Egypt
}

\author{
Bahaa Farrag \\ Animal physiology Department, Animal and Poultry Production Division, Desert Research Centre, Ministry of Agriculture and Land Reclamation, \\ Mataria, Cairo, Egypt \\ *Corresponding author`s Email: drc_bahaa@yahoo.com; ORCID: 0000-0003-2535-3681
}

\begin{abstract}
There are a few reports about the reproductive aspects or uses of both of flushing and estrus synchronization in Abou-Delik ewes grazing in the South Eastern zone of Egypt. Thirty-three Abou-Delik ewes were allocated to three experimental groups $(n=11$ in each) to study the effects of estrus synchronization and flushing on reproductive responses and productive characteristics under arid conditions of South Eastern zone of Egypt. Group one served as control represent the system dominant in the area (without estrus synchronization and flushing ration). Ewes in group two were estrous synchronized with two doses of $\mathrm{PGF}_{2} \alpha, 10$ days apart without flushing ration. Ewes in group three were estrous synchronized just like the second group and received $300 \mathrm{~g}$ of barley grain/head/day as flushing meal for three weeks before the start of breeding season. All ewes were grazed Panicum turgidum (natural vegetation dominant in the area) for eight hours daily. Results showed that, the percentage of estrus exhibition in group three reached $100 \%$, while the lowest percentage was observed in group one $(81.82 \%)$. Estrus activity signs in synchronized groups, occurred in 70 and $81.81 \%$ during the first $48 \mathrm{~h}$ after the second dose of $\mathrm{PGF}_{2} \alpha$, for groups two and three respectively, compared to control group $(22.22 \%)$. The onset of estrus was earlier in synchronized groups than control group. Duration of estrus did not differ significantly. Estrus intensity in group three was higher $(\mathrm{P}<0.05)$ compared to the other groups. Conception and lambing rates were $100 \%$ in group three. Third group showed the highest insignificant litter size that was $18 \%$ higher than the other groups. The overall mean of birth weight, weaning weight and average daily gain of Abou-Delik lambs were 2.91, 16.89 and $0.116 \mathrm{~kg}$, respectively. There is no significantly effect on concentrations of plasma progesterone among groups. While there were significant differences between sampling periods. In conclusion, under grazing on arid rangelands conditions in the South Eastern zone of Egypt, using flushing and/or estrus synchronization can be useful to improve reproductive and productive characteristics of Abou-Delik sheep.
\end{abstract}

Key words: Abou-Delik sheep, Estrus synchronization, Flushing, Productive performance, Rangelands, Reproduction

\section{INTRODUCTION}

Sheep is one of the most important grazing animals that have impacts on the economic and social status of people inhabiting semi-arid and arid regions. Grazing natural vegetation provides inexpensive source of nutrients. Abou-Delik sheep herds, under rangeland conditions, are subjected to a series of environmental stresses during a dry, mainly inadequate nutrition and insufficient drinking water. Additional energy expenditure for movement to range areas and watering does exist. Feed availability markedly affected sheep reproductive, especially when mating occurs in the dry season (Idris et al., 2010). The nutritional limitations under rangelands and harsh environment such as high scarcity of feed, water and ambient temperature conditions have a negative effect on sheep reproduction in semi-arid areas (El-Hag et al., 2001).

The breeding season of Abou-Delik breed in the South Eastern zone of Egypt coincides with the summer months. Under such circumstances, protein or energy-based supplementary feeding often referred as flushing, around the time of mating improves reproductive performance (Molle et al., 1995 and El-Hag et al., 1998). Feeding ewes on balanced rations for a short period prior to breeding season has been used to improve fecundity (Leury et al., 1990). This feeding method has implications on lambing rate. Flushing has been known as management practice commonly applied in commercial sheep flock to achieve higher fecundity. Flushing before mating and during lactation also affects milk yield and reproductive performance positively (Snyman, 2010). Also, it has been well known that flushing before mating and during lactation in animals shows positive effects on body condition score, ovulation rate and reproductive traits (Ray et al. 2012). 
On the other hand, estrus synchronization is a technique used for coordinating estrous cycle (Khaldari, 2008). Under semi intensive production systems, lambing rate efficiency and fecundity rate leading to high profitability of sheep holders could be enhanced using successful estrus synchronization programs (Knights et al., 2001). Estrus synchronization is a key element in all of the assisted reproductive technology protocols and has a major influence on enhancing the overall capabilities of reproductive function in ewes and does (Navanukraw et al., 2014).

Most recently, Kaya et al. (2018) noted that hormonal protocols are one of the main items to improve herds productivity. Prostaglandin $\mathrm{F}_{2} \alpha$ effectively synchronize estrus in sheep resulting in fairly good fertility rates. Prostaglandin $\mathrm{F}_{2} \alpha$ is produced by the uterus beginning around day 11 or 12 after estrus and causes the regression of the corpus luteum in non-pregnant ewe (Mekuriaw et al., 2016).

Since the response of sheep to synchronization appeared to be breed dependent, it was necessary to investigate whether synchronization with or without flushing could successfully increase estrus response rate and reproductive performance in Abou-Delik ewes. The experiment was designed to investigate the response of Abou-Delik breed under semi-intensive system in Halaieb - Shalateen - Abouramad triangle to estrus synchronization and flushing.

\section{MATERIALS AND METHODS}

\section{Location}

This study was carried out in Ras Hederba valley region at the Shalateen Research Station of the Desert Research Center, some $1300 \mathrm{~km}$ southeast of Cairo, Egypt, at latitude 22,00,720 N and longitude 36,48,955 E. The area is bordered by Sudan to the south and the red sea to the east. It is an arid region with average annual precipitation of $58.5 \mathrm{~mm} /$ year mostly as erratic showers in November and December. The average ambient temperature in the area ranges between $41.2^{\circ} \mathrm{C}$ and $24.8^{\circ} \mathrm{C}$, while the relative humidity is $86.8 \%$ (Central Laboratory for Agricultural Climate). Water resources are meager and available only to nomadic inhabitants and their animals from shallow wells. Therefore, settled agriculture activities are absent and grazing of sheep, goats and camels is the primary activity.

\section{Ethical approval}

This experiment was performed according to all ethics and animal rights (Desert Research Center). As much as this work had considering all rules and regulations in conformity with the European Union directive for the protection of experimental animals (2010/63/EU).

\section{Animals and grazing}

On July of 2017, 33 adult Abou-Delik ewes (2-4 years of age and $25.5 \pm 0.64 \mathrm{~kg}$ averaged live body weight) were maintained under grazing (free range) conditions. Animals grazed natural vegetation dominant in the area (Panicum turgidum) for eight hours daily in the morning from 06:00 to 12:00 and in the afternoon from 15:00 to 17:00 and after return from the pasture, they were supplemented with concentrate feed mixture (43\% yellow corn, $22 \%$ cotton seed meal, $20 \%$ wheat bran, $12 \%$ rice bran $1.5 \%$ limestone, $1 \%$ sodium chloride and $0.5 \%$ minerals mixture) at the rate of 250 $\mathrm{g} / \mathrm{head} /$ day covering their maintenance energy according to Kearl (1982). The chemical compositions of Panicum turgidum and the concentrate supplement are shown in table 1. Animals were examined clinically and were found to be free from physical abnormalities or reproductive disorders.

Table 1. The chemical composition of Panicum turgidum and concentrate feed mixture provided for Abou-Delik ewes in Halaieb - Shalateen - Abouramad triangle, Egypt

\begin{tabular}{lccc}
\hline \multirow{2}{*}{ Constituents } & \multicolumn{2}{c}{ Panicum turgidum } & $\begin{array}{c}\text { Concentrate feed mixture } \\
\text { (CFM) }\end{array}$ \\
\cline { 2 - 3 } Dry Matter & Summer (Dry) & Winter (Wet) & 91.25 \\
Organic matter & 57.1 & 44.2 & 91.07 \\
Crude Protein & 88.6 & 93.6 & 14.13 \\
Ether extract & 6.65 & 5.50 & 2.01 \\
Neutral detergent fiber & 1.20 & 1.82 & 62.34 \\
Acid detergent fiber & 88.0 & 89.7 & 9.57 \\
\hline
\end{tabular}

CFM: Concentrate feed mixture (\%, dry matter basis)

\section{Experimental design}

Ewes and rams of Abou-Delik sheep raised at Shalateen Research Station, Egypt were maintained separately during grazing period as well as during their stay at shed under semi intensive system of rearing under identical conditions of housing. Ewes were randomly assigned to three groups $(\mathrm{N}=11)$ as follows: Group 1, served as control without estrus synchronization and without flushing ration (system dominant in the area). Group 2, synchronized estrus with two $\mathrm{PGF}_{2} \alpha$ at a rate of $1 \mathrm{ml}$ for each injection (Estrumate, $250 \mu \mathrm{g}$ Cloprostenol/ ml, Schering-Plough Animal Health, Germany) intramuscularly injections given 10 days apart without flushing ration before mating period. Group 3, 
received flushing ration (300g of barley grain/ head/ day) three weeks before introducing rams. Estrus was synchronized with two $\mathrm{PGF}_{2} \alpha, 1 \mathrm{ml}$ intramuscularly injections given 10 days apart.

\section{Estrus detection and mating}

During the mating season (July, 2017), ewes were presented to three fertile Abou-Delik rams (1 ram / 11 ewes) and natural mating was allowed. The duration of the mating period was 17 days (equal to one estrus cycle length) in the control group. Synchronized groups ( 2 and 3 ) had four days (= $96 \mathrm{~h}$ ) for mating after second $\mathrm{PGF}_{2} \alpha$ injection. Paintedbreast fertile rams were introduced to ewes and left with them for estrus detection and natural mating. Rams were allowed to rotate among ewes in different groups (to avoid mixing effect for rams within groups).

Estrus detection was checked through the observation of the paint marks on the ewe's rumps. Ewes were considered in estrus and mating when the raddle mark was heavy and evenly distributed or when copulation was observed. Commencement of the estrus was defined as the time when the ewe first stood to be mounted by the ram. Duration of estrus was defined as the interval between the onset and end of estrus signs. The end of estrus was the time when the ewe refused to be further mounted.

The estrus intensity was measured as per the indications of Homeida et al. (2009) and Kumar et al. (2016) with a score card of degree of expression of restlessness (0-3), standing to be mounted (0-3), vocalization (0-3) and swelling of vulva and mucus discharges (0-3) and these parameters can reveal quantitatively weak estrus (0-4), intermediate estrus (5-8) and intense estrus (9-12) of animals. Reproductive and productive parameters were calculated according to Landais and Cissoko (1986), as follows:

Estrus response $(\%)=$ number of ewes showing estrus/total ewes treated in each group $\times 100$.

Conception rate $(\%)=$ number of pregnant ewes/number of ewes showing estrus and mated in each group $\times 100$.

Lambing rate $(\%)=($ number of ewes lambing /number of ewes mated $) \times 100$.

Abortion rate $(\%)=($ number of ewes aborted $/$ number of ewes mated $) \times 100$.

Litter size $=$ number of lambs born $/$ number of ewes lambed.

Mortality rate up to weaning $(\%)=$ lambs born alive - lambs weaned / lambs born alive $\times 100$.

\section{Blood collection and hormonal assay}

Blood samples $(5 \mathrm{ml})$ were withdrawn, in the morning before access to feed and water, from the jugular vein into EDTA tubes. The samples were collected during four periods as follows: first sampling, zero time (before ram introduction in control group and at first injection of $\mathrm{PGF}_{2} \alpha$ in groups 2 and 3), second sampling, four days after ram introduction in control group and four days after first injection of $\mathrm{PGF}_{2} \alpha$ in groups 2 and 3, third sampling, at day 10 in control group and at second injection of $\mathrm{PGF}_{2} \alpha$ in groups 2 and 3, fourth sampling at end mating period (on day 17 in control group and $96 \mathrm{~h}$ after second injection of $\mathrm{PGF}_{2} \alpha$ in groups 2 and 3). The samples were used to monitor the changes in plasma concentrations of progesterone $\left(\mathrm{P}_{4}\right)$. Plasma was harvested after centrifugation at $3000 \mathrm{rpm}$ for 15 minutes, and then stored at $-20^{\circ} \mathrm{C}$ for later analysis.

\section{Progesterone hormone assay}

Progesterone hormone $\left(\mathrm{P}_{4}\right)$ was quantified by ELISA method using BIOS kit (Chemux Bioscience Corporation South San Francisco, USA) according to Abraham (1981). The standard curve ranged between 0-50 ng/ml. The sensitivity of the curve was $0.2 \mathrm{ng} / \mathrm{ml}$.

\section{Statistical analysis}

The statistical analyses were conducted using GLM procedure of SAS (SAS, 2004). Chi-square ( $\chi 2)$ analysis was used to evaluate reproductive parameters differences. Differences $(\mathrm{P} \leq 0.05)$ between means were tested for significance using Duncan's multiple range test (Duncan, 1955).

\section{RESULTS AND DISCUSSION}

Abou-Delik sheep is one of the dominant breeds in the South Eastern zone of Egypt. The reports are rare regarding the reproductive aspects or use of flushing and synchronization on estrus activity and reproductive parameters of AbouDelik ewes which grazed in this region.

\section{Estrus activity}

Onset and duration of estrus and intensity of estrus are presented in table 2 . The onset of estrus was significantly $(\mathrm{P}<0.05)$ shorter in groups 2 and 3 than group 1. The interval between the time of second $\mathrm{PGF}_{2} \alpha$ injection and the onset of estrus between group 2 and group 3 was not significant $(\mathrm{P} \geq 0.05)$ whereas the onset of estrus was earlier in group 3 as compared with group 2. In the control group, estrus behavior was less concentrated and onset happened 159 hours after 
introduction of the rams. There was a significant difference $(\mathrm{P}<0.05)$ between unsynchronized and synchronized ewes. Considering that ewes in group 1 were mated within 17 days. The delay in G1 is attributed to the absence of estrus synchronization treatment in this group. The interval from the time of administration of second $\mathrm{PGF}_{2} \alpha$ injection to the time of first appearance of estrus behavior in G2 and G3 ewes was akin to the observations of Homeida et al. (2009) in Naeimi ewes (41.3 h) and Ashmawy (2012) in Rahmani ewes (42 to 49 h). Contreras-Solis et al. (2009) in West African ewes and Letelier et al. (2011) in Manchega ewes observed lower values of $32.49 \mathrm{~h}$ and $36 \mathrm{~h}$, respectively. While Zohara et al. (2014) in indigenous ewes observed longer interval from the time of the second $\mathrm{PGF}_{2} \alpha$ injection to the time of first appearance of behavioral estrus $(55-58 \mathrm{~h})$ which was comparable to the present results.

Table 2. Estrus response, onset, duration and intensity of estrus in unsynchronized and synchronized Abou-Delik ewes which grazing on arid rangelands in Halaieb - Shalateen - Abouramad triangle, Egypt

\begin{tabular}{|c|c|c|c|c|}
\hline Variable & G1 & G2 & G3 & Overall mean \\
\hline Number of ewes & 11 & 11 & 11 & \\
\hline Number of ewes in estrus & 9 & 10 & 11 & \\
\hline Onset of estrus (h) & $159.55 \pm 20.21^{\mathrm{a}}$ & $44.30 \pm 19.18^{\mathrm{b}}$ & $40.54 \pm 18.28^{b}$ & $77.50 \pm 14.62$ \\
\hline Duration of estrus (h) & $27.33 \pm 1.69^{\mathrm{a}}$ & $29.80 \pm 1.60^{\mathrm{a}}$ & $31.27 \pm 1.53^{\mathrm{a}}$ & $29.60 \pm 0.94$ \\
\hline Intensity of estrus & $5.77 \pm 0.69^{b}$ & $6.60 \pm 0.75^{\mathrm{b}}$ & $7.45 \pm 0.72^{\mathrm{a}}$ & $6.66 \pm 0.44$ \\
\hline Weak estrus \% (N) & $22.22(2 / 9)$ & $10(1 / 10)$ & $0(0 / 11)$ & \\
\hline Intermediate estrus \% $(\mathrm{N})$ & $66.66(6 / 9)$ & $70.0(7 / 10)$ & $72.72(8 / 11)$ & \\
\hline Intense estrus \% $(\mathrm{N})$ & $11.11(1 / 9)$ & $20(2 / 10)$ & $27.27(3 / 11)$ & \\
\hline
\end{tabular}

G1: Unsynchronized and not flushed; G2: Synchronized and not flushed and G3: Synchronized and flushed; N: number; ${ }^{\mathrm{a}, \mathrm{b}, \mathrm{c}}$ means in the same row bearing different superscripts are significantly different $(\mathrm{P}<0.05)$

The duration of estrus was found to be $27.33,29.80$ and $31.27 \mathrm{~h}$ in G1, G2 and G3, respectively with differences being insignificant $(\mathrm{P}<0.05)$, although $\mathrm{G} 3$ showed the longer duration of estrus (Table1). Further, slightly longer duration of estrus observed in the present investigation in group 3 might be due to flushing before mating. The overall mean of estrus duration of Abou-Delik ewes was $29.60 \mathrm{~h}$. Results of the present study agreed with that recorded by Naqvi et al. (1997) in Kheri ewes (28.5 to $30.6 \mathrm{~h}$ ) and Zohara et al. (2014) in indigenous ewes (30.5 to $31.6 \mathrm{~h}$ ). Daghash et al. (2017) found that the duration of estrus in Egyptian ewe lambs were $32.5 \mathrm{~h}$ in control group, $29 \mathrm{~h}$ in group treated with $\mathrm{PGF}_{2} \alpha$ and $31.62 \mathrm{~h}$ in flushed group. However, Homeida et al. (2009) found that the duration of estrus in Naeimi ewes after second injection of $\mathrm{PGF}_{2} \alpha$ was earlier $(16.2 \mathrm{~h})$ compared to the present experiment.

Intensity of estrus measured in ewes was 5.77, 6.60 and 7.45 in G1, G2 and G3, respectively. The intensity of estrus score was significantly $(\mathrm{P}<0.05)$ higher in group 3 compared to other groups. Estrus intensity of ewes synchronized in this study (6.60 and 7.45) higher than estrus intensity in Naeimi ewes synchronized with PGF $_{2} \alpha(6.0)$. The overall mean of estrus intensity was close with that of in Nellore Jodipi ewes synchronized with $250 \mu \mathrm{g}$ cloprostenol, $\mathrm{PGF}_{2} \alpha$ (6.83). Present results are similar to those of Kumar et al. (2016) reported that intensity of estrus was 7.38 and 7.47 in ewe lambs synchronized by progesterone intra vaginal sponge for 12 days along with Pregnant Mare Serum Gonadotropin (PMSG) 200 and 300 IU. Among the groups only the percentages of weak estrus were $22.22 \%, 10 \%$ and $0 \%$ in groups 1,2 and 3, respectively. Percentages of intermediate estrus were shown by $66.66 \%$, $70.0 \%$ and $72.72 \%$ in groups 1,2 and 3 , respectively. The intense estrus values were indicated by $11.11 \%, 20 \%$ and $27.27 \%$ in groups 1, 2 and 3, respectively. The most intensity of estrus symptoms was in intermediate estrus and consisted of $66.66 \%, 70 \%$ and $72.72 \%$ in groups 1,2 and 3, respectively, these results conform to those of some earlier studies on the intensity of estrus symptoms, Kumar (2015) reported that intensity of estrus symptoms were intermediate in $94.22 \%$ and $88.89 \%$ ewes. Kumar et al. (2016) found that intermediate estrus was $75 \%$ and $64.71 \%$ in ewe lambs. Differences in the various studies might also be due to breed variation, nutrition, season and geographical location (Zonturlu et al., 2008; Zohara et al., 2014).

The number of ewes exhibiting estrus was 9, 10 and 11 out of 11 ewes in groups 1, 2 and 3, respectively. Estrus detection during $408 \mathrm{~h}$ (17 days) after ram introduction in group 1 (Figure 1) and during $96 \mathrm{~h}$ (4 days) after second ejection of $\mathrm{PGF}_{2} \alpha$ and ram introduction in groups 2 and 3 presented in (Figure 2). In group 1 estrus activity signs were detected in $22.22 \%$ of ewes at 24, 96 and $264 \mathrm{~h}$, while $11.11 \%$ of ewes were detected in 168,192 and 312 h during estrus cycle. Whereas they were observed within $24 \mathrm{~h}(20 \%$ and $27.27 \%)$ and were detected within $48 \mathrm{~h}$ in the vast majority (50\% and 54.54\%) and within $72 \mathrm{~h}(20 \%$ and $18.18 \%)$ and within $96 \mathrm{~h}(10 \%$ and none) in groups 2 and 3 , respectively. Overall, in synchronized groups, estrus activity signs occurred at a narrow range (70\% and $81.81 \%$ for G2 and G3, respectively) of total ewes showed estrus during the first $48 \mathrm{~h}$ after the second dose of $\mathrm{PGF}_{2} \alpha$ than unsynchronized group (G1) which was $22.22 \%$ during same period, this due to no using protocol of estrus synchronization in G1. According to Yildiz et al. (2004), the nutritional status of sheep also influences luteinizing hormone secretion. In this study, estrus expression was detected within $48 \mathrm{~h}$ following the second injection of $\mathrm{PGF}_{2} \alpha$ in the vast majority $(50 \%$ and $54.54 \%)$ of ewes in synchronized groups (G2 and G3). Sozabilir et al. (2006) found that the signs of estrus were detected within $48 \mathrm{~h}$ 
in the vast majority $\left(92.3 \%\right.$ and $60 \%$ ) of ewes following the second injection of $\mathrm{PGF}_{2} \alpha$ in two groups (with 10 vs. 14 day intervals, respectively). Menchaca et al. (2004) reported that estrus behavior was observed within 72 hours after the second dose of $\mathrm{PGF}_{2} \alpha$ in $93.9 \%$ and $82.4 \%$ of multiparous and nulliparous ewes, respectively. Similarly, Godfrey et al. (1997) observed that within $72 \mathrm{~h}, 71.4 \%$ of ewes came into estrus after the second injection of $\mathrm{PGF}_{2} \alpha$. This result is in agreement with study of Menchaca et al. (2004) that observed $80 \%$ of ewes with estrus expression between 25 and $48 \mathrm{~h}$ after treatment with double injections of $\mathrm{PGF}_{2} \alpha$ analogs within seven days interval. Which confirmed present results, Wildeus et al. (1989) reported that hair ewes that were flushed for four weeks prior to breeding exhibited estrus earlier in the breeding season than ewes that were not flushed.

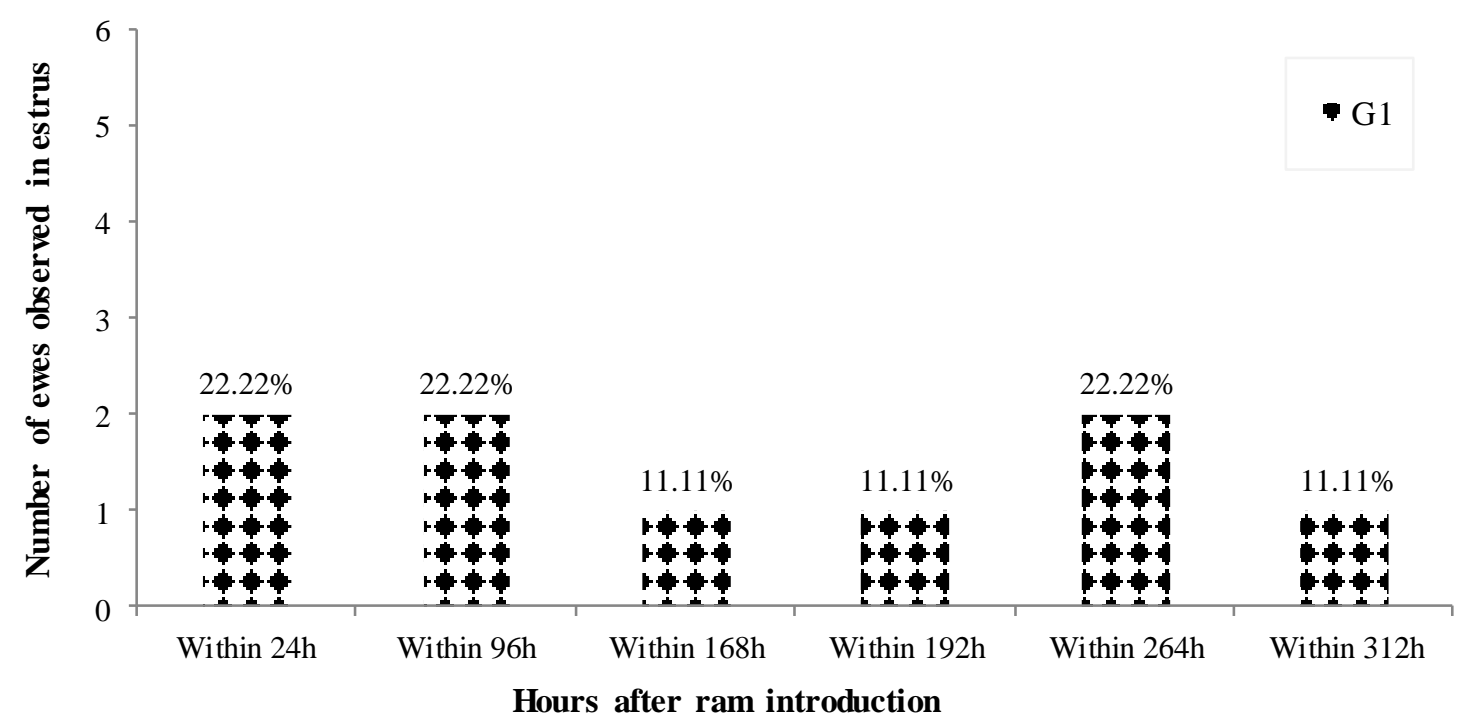

Figure 1. Distribution of estrus activity during 17 days $(=408 \mathrm{~h})$ after ram introduction of Abou-Delik ewes unsynchronized (G1: Unsynchronized and un-flushed)

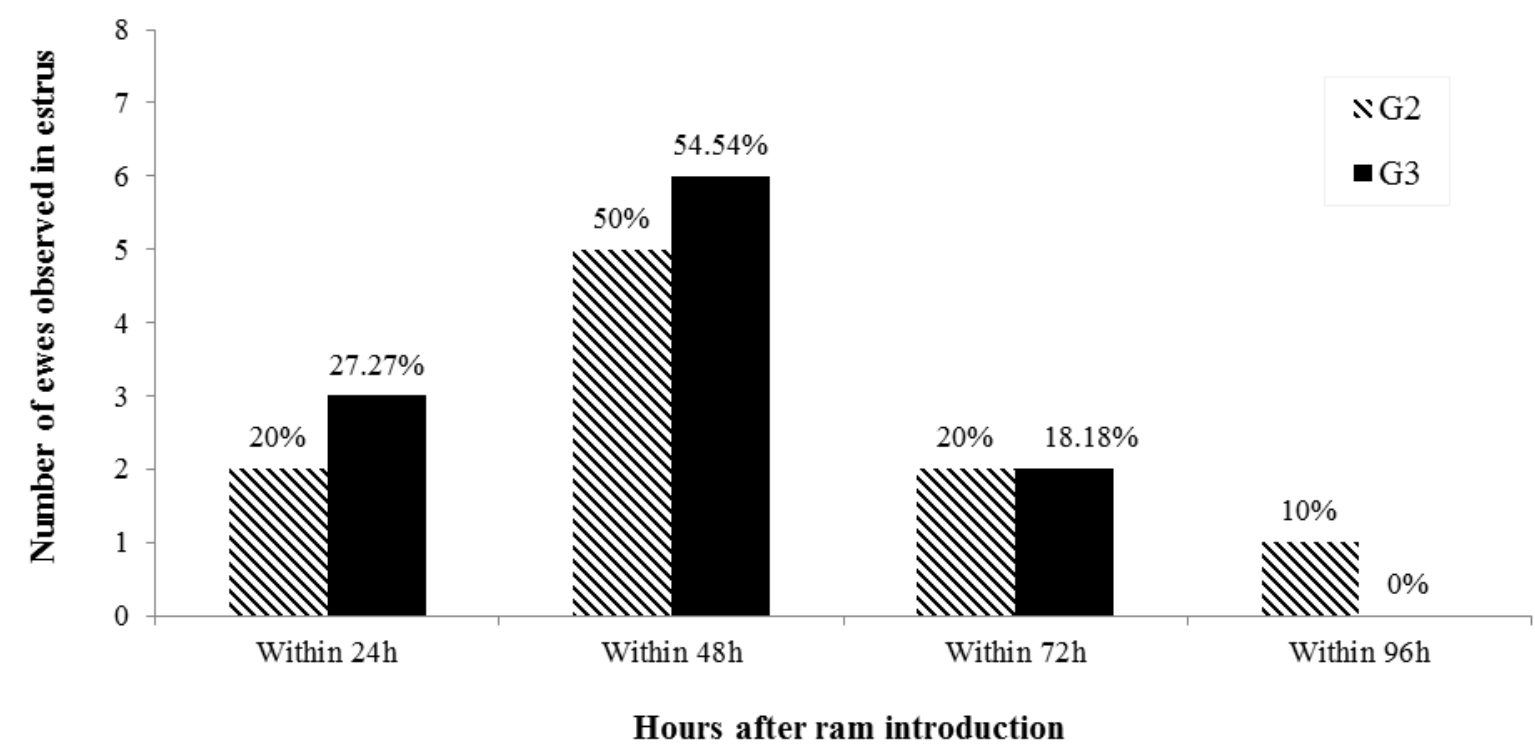

Figure 2. Distribution of estrus activity during 96 hours after ram introduction of Abou-Delik ewes synchronized with double injections of $\mathrm{PGF}_{2} \alpha$ (G2: Synchronized and un-flushed and G3: Synchronized and flushed)

\section{Reproductive responses}

Estrus response, conception, abortion, lambing rates, litter size and sex of lambs of Abou-Delik ewes are presented in table 3. Estrus response was 81.82, 90.91 and $100 \%$ in the groups 1, 2 and 3, respectively. Conception rate was $100 \%$ in all groups. Abortion rates were 11.11, 10 and 0\%, lambing rates were 88.89, 90 and 100\% and litter size was 100,100 and $118 \%$ in groups 1, 2 and 3, respectively. While, sex of lambs was 50\% males and 50\% females, 55.56\% males and $44.44 \%$ females, $61.54 \%$ males and $38.46 \%$ females in the groups 1,2 and 3, respectively. There were no statistically significant differences $(\mathrm{P}>0.05)$ for the estrus response, conception, abortion, lambing rates and sex of lambs between these groups. 
Table 3. Some reproductive responses of Abou-Delik ewes which grazing on arid rangelands in Halaieb - Shalateen Abouramad triangle, Egypt

\begin{tabular}{|c|c|c|c|c|}
\hline Variable & G1 & G2 & G3 & Chi value \\
\hline Number of ewes & 11 & 11 & 11 & \\
\hline Estrus response $\%(\mathrm{~N})$ & $81.82(9)$ & $90.91(10)$ & $100.00(11)$ & 2.04 \\
\hline Conception rate $\%(\mathrm{~N})$ & $100.00(9)$ & $100.00(10)$ & $100.00(11)$ & 2.25 \\
\hline Abortion rate $\%(\mathrm{~N})$ & $11.11(1)$ & $10.00(1)$ & $0.00(0)$ & 1.98 \\
\hline Number of barren ewes & 3 & 2 & 0 & \\
\hline Lambing rate $\%(\mathrm{~N})$ & $88.89(8)$ & $90.00(9)$ & $100.00(11)$ & 1.98 \\
\hline Litter size $(\%)$ & 100 & 100 & 118 & 1.98 \\
\hline \multicolumn{5}{|l|}{ Sex of lambs } \\
\hline Male \% (N) & $50.00(4)$ & $55.56(5)$ & $61.54(8)$ & 0.63 \\
\hline Female $\%(\mathrm{~N})$ & $50.00(4)$ & $44.44(4)$ & $38.46(5)$ & 0.63 \\
\hline
\end{tabular}

G1: Unsynchronized and not flushed; G2: Synchronized and not flushed and G3: Synchronized and flushed; N: number

In the present study, use of estrus synchronization program allowed to induce the estrus response in 90.91 and $100 \%$ of the ewes in the groups 2 and 3, respectively, which were higher than control group (G1, 81.82\%). Similar result was reported by Waheeb et al. (2017) that reported $90 \%$ estrus induction rate using two injections of PGF $2 \alpha$ in Barki ewes compared to control group (60\%). The present results were similar to those reported by Ozturkler et al. (2003) and Sozbilir et al. (2006) in Tuj ewes (100\%) and Zohara et al. (2014) indigenous ewes (100\%). In contrast, Godfrey et al. (1997) observed that $71.4 \%$ of females came into estrus after the second application of $\mathrm{PGF}_{2} \alpha$. Kumar (2015) found that estrus response observed by using apronized ram in synchronized ewes and treated with $250 \mu \mathrm{g} \mathrm{PGF}_{2} \alpha$ was $85.71 \%$. Homeida et al. (2009) reported estrus response to be $80 \%$ in Naeimi ewes treated with $\mathrm{PGF}_{2} \alpha$. Further, the lower percentage of estrus response observed in control group could be due to not using estrus synchronization program. This higher rate of estrus detection in group 3 might be due to use of flushing regime before mating. Variations in estrus response rate and the discrepancies between the results in the literature could be attributed to the difference in the breed variations, nutrition, seasonality effect, climatic and environment factors (Das et al., 1999; Dogan et al., 2006).

Conception rate was $100 \%$ in all groups with no significant difference among each group (P>0.05). These results were in agreement with results gained by Yavuzer et al. (2010) who used double injection of PGF $_{2} \alpha, 10$ days apart with or without injection of follicle stimulating hormone (FSH) and obtained 100 and $95 \%$ conception rates, respectively. In contrast to present investigation, Zohara et al. (2014) observed conception rate was $75 \%$ in Bangladesh indigenous ewes synchronized by two doses of $\mathrm{PGF}_{2} \alpha(175 \mu \mathrm{g})$. Kumar (2015) found that conception rate $80.95 \%$ in Nellore Jodipi ewes treated with $250 \mu \mathrm{g} \mathrm{PGF}_{2} \alpha$. Present findings recorded in conception rate were higher than the findings of Homeida et al. (2009) in Naeimi ewes treated with $\mathrm{PGF}_{2} \alpha(81.25 \%)$. Furthermore, variations in conception rate observed among different studies might be due to difference in the breed (Karagiannidis et al., 2001) and breeding season (Ataman et al., 2006).

Abortion rates were $11.11,10$ and $0 \%$ in the groups 1, 2 and 3, respectively. The effects of pregnancy stress on ewes are manifested in increased abortions, weight loss and mortality. It was observed that un-flushed ewes were higher in abortion percentage compared to flushed ewes, which may be ascribed to the effect of flushing before mating (Yoder et al., 1990).

The highest lambing rate $(100 \%)$ was in group 3 when compared to other groups $(88.89 \%$ in group 1 and $90 \%$ in group 2) but there was no significant difference $(\mathrm{P} \geq 0.05)$ between the groups. Present findings recorded in synchronized groups were higher than the findings of Sozbilir et al. (2006) who have reported lambing rate in Tuj ewes $60 \%$ and $73 \%$ with double injections of $\mathrm{PGF}_{2} \alpha$ at 10 and 14 day intervals respectively. Ozturkler et al. (2003) reported that lambing rate in Tuj ewes double injected with $0.075 \mathrm{mg}$ of $\mathrm{PGF}_{2} \alpha$ at 11 day intervals was $53.3 \%$. The present results were not consistent with these mentioned reports, which may be due to the high lambing rate in Abou-Delik sheep (ranged from $89-100 \%)$.

Litter size in ewes is shown in table 3. Increasing sheep productivity by increasing lambing rate, litter size and fertility rates was considered as an important factor in the development of sheep production. In the present study, there was an increase in litter size in third group as compared to the other groups. The mean litter size in groups 1,2 , and 3 were 100, 100 and $118 \%$, respectively. Third group showed the best results, with litter size that was $18 \%$ higher than the other groups. Although there was no difference in the rates of litter size among the treatment groups $(\mathrm{P}>0.05)$, it is interesting to note that twin births only occurred among the nutritionally flushed ewes. The highest litter size was obtained in third group, and this can be ascribed to the increase energy-based supplementary feeding (flushing) before the mating season. These results agree well with those reported by Ribeiro et al. (2002) for ewes supplemented with 0.5 $\mathrm{kg}$ per animal of ground corn. Similar benefits on litter size and lambing rates after flushing were described by El-Hag et al. (1998). In line with these results Marzouk et al. (2018) reported that enhancing ration during breeding period is enough to improve the reproductive performance of Ossimi ewes. 


\section{Gestation period}

The average gestation length period was $157.37,154.88$ and 153.45 days for G1, G2 and G3, respectively (Table 4). Gestation length was significantly $(\mathrm{P}<0.05)$ shorter in group 3 compared with other groups. Sex of lamb had no significant $(\mathrm{P}>0.05)$ effect on gestation period which was 155 days in ewes carrying males and 154.84 days in ewes carrying females. Likewise, type of birth had no effects on gestation period (155.11 \pm 0.37 days in ewes carrying singles vs. 154.00 \pm 1.36 days in ewes carrying twins).

Variations were found in gestation period as a result of treatment (Table 4). The average gestation period was 155 days, ranging from shorter average of 153.45 days for ewes on G3 to longer gestation period of 157.37 days for ewes on G1. Furthermore, sex of lamb and lamb type of birth exerted no main effects on gestation period. Moreover, Aboul-Ella (2006) reported that length of gestation period was shorter in ewes treated with PG-600 and flushing in Barki ewes. As well Safranski et al. (1992) reported that pregnancy period in control ewes and ewes treated with melengestrol acetate + PG-600 was 163.8 and 157.2 days, respectively. In contrast, Zarkawi (2000) reported that the treatment had no effect on the duration of pregnancy, which averaged 150.3 days in control and 150.4, and 150.8 days in synchronized groups with $10 \mathrm{mg}$ and $15 \mathrm{mg} \mathrm{PGF}_{2} \alpha$, respectively. This difference can be likely due to the different breed of sheep and the environment. The long gestation period in the groups that did not flushed because of the breeding and gestation periods are thus in the dry season when the rangelands are at their lowest nutritional quality, this is reflected in high gestation length period and high abortion rates.

Table 4. Effect of treatment, sex and birth type on gestation length (mean \pm S.E) of Abou-Delik ewes which grazing on arid rangelands in Halaieb - Shalateen - Abouramad triangle, Egypt

\begin{tabular}{lccc}
\hline Items & Factors & N & Gestation Period, days \\
\hline \multirow{2}{*}{ Treatment } & G1 & 8 & $157.37 \pm 0.37^{\mathrm{a}}$ \\
& $\mathrm{G} 2$ & 9 & $154.88 \pm 0.34^{\mathrm{b}}$ \\
\hline \multirow{2}{*}{ Sex of lamb } & $\mathrm{G} 3$ & 13 & $153.45 \pm 0.31^{\mathrm{c}}$ \\
\hline \multirow{2}{*}{ Lamb type of birth } & Male & 17 & $155.00 \pm 0.46^{\mathrm{a}}$ \\
& Female & 13 & $154.84 \pm 0.53^{\mathrm{a}}$ \\
\hline Overall Mean & Single & 26 & $155.11 \pm 0.37^{\mathrm{a}}$ \\
a,b, means in the same column bearing different superscripts are significantly different $(\mathrm{P}<0.05) ; \mathrm{N}:$ number & 4 & $154.00 \pm 1.36^{\mathrm{a}}$ \\
\hline
\end{tabular}

\section{Productive characteristics}

The effect of experimental groups on birth weight, weaning weight, average daily gain and mortality rate are presented in table 5. There were no significant $(\mathrm{P}>0.05)$ differences among the experimental groups in productive characteristics of Abou-Delik ewes. The overall mean of birth weight, weaning weight and average daily gain of AbouDelik ewes were $2.91,16.89$ and $0.116 \mathrm{~kg}$ respectively. Higher birth weight was observed in lambs born in G3 (3.02 kg) than the other groups. However, there was no significant difference observed $(\mathrm{P}>0.05)$. The birth weight in lambs of $\mathrm{G} 3$ was higher than other groups which could be attributed to flushing of ewes. Flushing significantly affected litter weight at birth and weaning (Sormunen-Cristian and Jauhiainen, 2002). This finding is in agreement with El-Hag et al. (1998) who reported higher birth weights in ewes supplemented with flushing ration during breeding time as compared to ewes which were not supplemented. Average weaning weights of lambs at three months of age was found as $16.89 \mathrm{~kg}$. Weaning weight of lambs in G3 $(17.19 \mathrm{~kg})$ was higher than those in other groups (16.27 kg for group 1 and $16.98 \mathrm{~kg}$ for group 2). Zhang et al. (2008) reported that weaning weight was affected by birth weight. The current results are in line with this imposition. Average daily gain in groups was estimated to 118, 125 and $128 \mathrm{~g}$ in groups 1, 2, and 3, respectively. Mortality rate from birth until weaning in groups 1, 2, and 3 were estimated to $12.5,0$ and $7.69 \%$, respectively.

Table 5. Least squares means $( \pm \mathrm{SE}$ ) for productive characteristics of Abou-Delik ewes which grazing on arid rangelands in Halaieb - Shalateen - Abouramad triangle, Egypt

\begin{tabular}{lcccc}
\hline Traits & G1 & G2 & G3 & Overall mean \\
\hline Birth weight $(\mathrm{kg})$ & $2.91 \pm 0.11$ & $2.93 \pm 0.13$ & $3.02 \pm 0.08$ & $2.91 \pm 0.06$ \\
Weaning weight $(\mathrm{Kg})$ & $16.27 \pm 0.79$ & $16.98 \pm 0.93$ & $17.19 \pm 0.87$ & $16.89 \pm 0.50$ \\
Average daily gain $(\mathrm{g})$ & $118.0 \pm 6.83$ & $125.0 \pm 7.57$ & $128.0 \pm 6.84$ & $116.0 \pm 4.04$ \\
Mortality rate $(\%)$ & $12.50 \pm 9.12$ & $0.0 \pm 8.60$ & $7.69 \pm 7.15$ & $6.66 \pm 4.63$ \\
\hline
\end{tabular}

G1: Unsynchronized and not flushed; G2: Synchronized and not flushed and G3: Synchronized and flushed 


\section{Progesterone concentration}

There were no significant $(\mathrm{P}>0.05)$ effects of treatments on progesterone concentrations but there were significant $(\mathrm{P}<0.05)$ effects of sampling periods on the concentrations of plasma progesterone (Table 6). The mean progesterone concentrations were $2.80,2.48$ and $2.09 \mathrm{ng} / \mathrm{ml}$ in groups 1,2 and 3 , respectively. While, the overall mean progesterone concentrations were $3.55,1.28,3.79$ and $1.20 \mathrm{ng} / \mathrm{ml}$ on first sampling, second sampling, third sampling and fourth sampling, respectively. The obtained results from this experiment indicated that the mean progesterone concentrations in second sampling (1.56 and $1.18 \mathrm{ng} / \mathrm{ml})$ and fourth sampling $(0.89$ and $0.71 \mathrm{ng} / \mathrm{ml})$ decreased after the first and second injection of $\mathrm{PGF}_{2} \alpha$ as compared to first sampling ( 3.34 and $\left.2.78 \mathrm{ng} / \mathrm{ml}\right)$ and third sampling ( $4.14 \mathrm{and} 3.71 \mathrm{ng} / \mathrm{ml}$ ) before first and second injection of $\mathrm{PGF}_{2} \alpha$. This result was similar to the presented results by Demiral et al. (2008) in Akkaraman ewes treated with $\mathrm{PGF}_{2} \alpha$, in nine days interval. The mean plasma progesterone concentration in $\mathrm{PGF}_{2} \alpha$ synchronized ewes estimated in first sampling (at prostaglandin first dose) was $3.55 \mathrm{ng} / \mathrm{ml}$. Similar progesterone concentration was observed by Demiral et al. (2008) in Akkaraman ewes $(2.67 \mathrm{ng} / \mathrm{ml})$. Progesterone concentration decreased in second sampling (four days after first dose of prostaglandin) was $1.28 \mathrm{ng} / \mathrm{ml}$. This result was in accordance with that observed by Homeida et al. (2009) in Naeimi ewes $\left(1.1 \mathrm{ng} / \mathrm{ml}\right.$ ). The $\mathrm{P}_{4}$ concentration on third sampling (at day of the second $\mathrm{PGF}_{2} \alpha$ injection) was $3.79 \mathrm{ng} / \mathrm{ml}$, this result was accordance with observed progesterone concentration by Naderipour et al. (2012) in Kalkuhi ewes $(3.76 \mathrm{ng} / \mathrm{ml}$ ) and Sozbilir et al. (2006) in Tuj ewes $4.29 \mathrm{ng} / \mathrm{ml}$. The progesterone concentration in day four after mating was $1.20 \mathrm{ng} / \mathrm{ml}$, the average progesterone concentrations decreased significantly on day four after the second injection of $\mathrm{PGF}_{2} \alpha$ as compared to the prior of the second injection. Plasma progesterone concentrations on day four after the second injection of $\mathrm{PGF}_{2} \alpha$ indicated the regression of corpus luteum. The progesterone concentration values of present study are in line with Sozbilir et al. (2006) and Naderipour et al. (2012).

Table 6. Mean $( \pm \mathrm{SE})$ plasma progesterone concentrations of control and synchronized Abou-Delik ewes which grazing on arid rangelands in Halaieb - Shalateen - Abouramad triangle, Egypt

\begin{tabular}{|c|c|c|c|c|c|}
\hline \multirow{2}{*}{ Item } & \multirow{2}{*}{$\begin{array}{l}\text { Sampling } \\
\text { periods }\end{array}$} & \multicolumn{3}{|c|}{ Groups } & \multirow{2}{*}{$\begin{array}{c}\text { Overall } \\
\text { mean }\end{array}$} \\
\hline & & G1 & G2 & G3 & \\
\hline \multirow{5}{*}{$\mathrm{P}_{4}(\mathrm{ng} / \mathrm{ml})$} & First & $4.54 \pm 0.88$ & $3.34 \pm 0.83$ & $2.78 \pm 0.65$ & $3.55^{\mathrm{a}} \pm 0.46$ \\
\hline & Second & $1.12 \pm 0.30$ & $1.56 \pm 0.46$ & $1.18 \pm 0.27$ & $1.28^{\mathrm{b}} \pm 0.19$ \\
\hline & Third & $3.54 \pm 0.71$ & $4.14 \pm 0.51$ & $3.71 \pm 0.97$ & $3.79^{\mathrm{a}} \pm 0.41$ \\
\hline & Fourth & $2.02 \pm 0.45$ & $0.89 \pm 0.06$ & $0.71 \pm 0.10$ & $1.20^{\mathrm{b}} \pm 0.21$ \\
\hline & Overall mean & $2.80 \pm 0.41$ & $2.48 \pm 0.39$ & $2.09 \pm 0.39$ & --- \\
\hline
\end{tabular}

G1: Unsynchronized and not flushed; G2: Synchronized and not flushed and G3: Synchronized and flushed; ${ }^{\mathrm{a}, \mathrm{b}}$ Means of period with differen superscripts are significant differences $(\mathrm{P}<0.05) ; \mathrm{P}_{4}$ : progesterone concentrations

\section{CONCLUSION}

Under grazing conditions in arid rangelands in the South Eastern zone of Egypt, using flushing and estrus synchronization can be useful to improve reproductive and productive responses of Abou-Delik sheep. The present study indicates that both flushing and estrus synchronization improved reproductive responses of Abou-Delik ewes particularly estrus response, lambing rate and litter size. It is clear during the results of the present experiment that the Abou-Delik sheep breed is a good breed originally under grazing conditions in arid zones and we need further studies and bigger numbers of sheep to confirm this.

\section{DECLARATIONS}

\section{Acknowledgments}

The author is thankful to Dr. Ali Saber Morsy for assisting statistical analysis. Deepest thanks are due to Dr. Essam Tharwat, Dr. Hamdy Gawish and Dr. Salah Attia for their review of this manuscript. Special thanks are due to the workers of Ras Hederba valley farm at the Shalateen Research Station for making available the facilities and kind help during the experimental work.

\section{Competing interests}

The author declares that he has no conflict of interest with respect to the research, authorship, and/or publication of this article, the author declares that he has no competing interests.

\section{REFERENCES}

Aboul-Ella AA (2006). Response of Barki ewes to treatment with gonadotrophin hormones and energy supplementation (flushing). Egyptian Journal of Sheep. Goat and Desert Animals Sciences, 1(1):73-88. DOI: https://10.21608/ejsgs.2006.28139 
Abraham GE (1981). The application of natural steroid radioimmunoassay to gynecologic endocrinology. In: Abraham GE, editor. Radioassay Systems in Clinical Endocrinology, Basel: Marcel Dekker, pp: 475-529.

Ashmawy TAM (2012). Effect of ovarian synchronization protocols, using GnRH and $\mathrm{PGF}_{2} \alpha$, on ovarian response and reproductive traits of Rahmani ewes. Egyptian Journal of Sheep and Goat sciences, 7(2):43-49. DOI: https://10.21608/EJSGS.2012.27010

Ataman MB, Akoz M and Akman O (2006). Induction of synchronized oestrus in Akkaraman cross-breed ewes during breeding and anestrous seasons: the use of short-term and long-term progesterone treatments. Revue de Médecine Vétérinaire, 157(5):257260.

Contreras-Solis I, Vasquez B Diaz T, Letelierb C, Lopez-Sebastian and Gonzales-Bulnes A (2009). Efficiency of estrous synchronization in tropical sheep by combining short-interval cloprostenol-based protocols and "male effect". Theriogenology, 71:1018-1025. DOI: https://10.1016/j.theriogenology,2008.11.004

Daghash H, Fahmy S, Hassan T and Ali M (2017). Impact of GnRH, PMSG and hCG treatments on follicular diameter, conception and lambing rates of Egyptian ewe lambs using intravaginal sponges. Egyptian Journal of Sheep and Goat Sciences, 12 (1): 1-8. DOI: https:// 10.12816/0035353

Das GK Naqvi, SMK, Gulyani R, Anil Joshi, Pareek SR and Mittal JP (1999). Estrus synchronization response in Malpura ewes treated with $\mathrm{PGF}_{2} \alpha$. Indian Journal of Animal Science, 69(10):797-798.

Demiral OO, Un M, Abay M, BekyUrek T and Atabay NO (2008). The effectiveness of synchronization of estrus via prostaglandin $\mathrm{F}_{2} \alpha$ administration and timed artifical insemination in multipar and nullipar Akkaraman breed ewes. Research Journal of Animal Science, 2(2):14-44. Available at: https://www.researchgate.net/publication/237268954

Dogan I and Nur Z (2006). Different estrus induction methods during the non-breeding season in Kivircik ewes. Veterinarni Medicina, 51(4): 133-138. DOI: https://10.17221/5532-VETMED

Duncan DB (1955). Multiple ranges and multiple F test. Biometrics, 11: 1-15.

El-Hag FM, Fadlalla B and Elmadih MA (1998). Effect of strategic supplementary feeding on ewe productivity under range conditions in north Kordofan, Sudan. Small Ruminant Research, 30:67-71. DOI https://10.1016/S0921-4488(98)00080-7

El-Hag FM, Fadlalla B and Mukhtar HK (2001). Some production characteristics of Sudan Desert sheep under range conditions in north Kordofan, Sudan. Tropical Animal Health and Production, 33: 229-239. DOI: https://10.1023/A:1010366805607

Godfrey RW, Gray ML and Collins JR (1997). A comparison of two methods of oestrous synchronization of hair sheep in the tropics. Animal Reproduction Science, 47:99-106. DOI: https://10.1016/S0378-4320(97)00007-9

Homeida AM, AL-Mubarak AI and AL-Yousef YM (2009). Synchronization of estrus in Naeimi ewes following treated with progesterone and prostaglandin $\mathrm{F}_{2} \alpha$. Scientific Journal of King Faisal University, 10(2): 95-103.

Idris AO, Kijora C, El-Hag FM and Salih AM (2010). Effect of dietary supplementation on reproductive performance of Sudanese Desert sheep. Livestock Research for Rural Development, 22 (8). Available at: http://www.lrrd.org/lrrd22/8/idri22140

Karagiannidis A, Varsakeli S, Karatzas G and Brozos C (2001). Effect of time of artificial insemination on fertility of progestagen and PMSG treated indigenous Greek ewes, during non-breeding season. Small Ruminant Research, 39:67-71. DOI https://.org/10.1016/S0921-4488(00)00170-X

Kaya A, GNes E and Memili E (2018). Application of reproductive biotechnologies for sustainable production of livestock in Turkey. Turkish Journal of Veterinary and Animal Sciences, 42:143-151. Doi: https:// 10.3906/vet-1706-66

Kearl IC (1982). Nutrient Requirements of Ruminants in Developing Countries, International Feedstuffs Utilization. Utah Agricultural Experiment Station, Utah State University, Logen, UT, USA.

Khaldari M (2008). Principles in Sheep and Goat Rearing. Jahad Daneshgahy Tehran Publications. Tehran, Iran.

Knights M, Maze TD, Bridges PJ Lewis PE and Inskeep EK (2001). Short-term treatment with a controlled internal drug releasing (CIDR) device and FSH to induce fertile estrus and increase prolificacy in anestrous ewes. Theriogenology, 55:1181-1191. DOI: https:// 10.1016/S0093-691X(01)00476-9

Kumar BH, Bramhaiah KV Srinivas M, Ekambaram B and Dhanalakshmi N (2016). Effect of estrus synchronization by progesterone sponge along with PMSG on estrus response and fertility in Nellore Jodipi ewe lambs. Theriogenology, Insight: 6(3):135-141. DOI: https:// 10.5958/2277-3371.2016. 00019.X

Kumar KP (2015). Evaluation of estrus synchronization with different doses of prostaglandin $\mathrm{F}_{2} \alpha$ in Nellore Jodipi ewes. M.Sc. Thesis veterinary science. Sri Venkateswara Veterinary University.1-58. Available at: https://krishikosh.egranth.ac.in/handle/1/5810012934

Landais E and Cissoko MM (1986). Methodological bases for measuring animal performances, IEMVT/ISRA, pp. 433-485.

Letelier CA, Contreras-Solis I, Garcia-Fernandez Sanchez MA, Garcia-Palencia Sanchez B, Ariznavarreta C, Tresguerres JAF, Flores JM and Gonzalez-Bulnes A (2011). Effect of Oestrus induction with progesterone or prostaglandin analogues on ovarian and pituitary function in sheep. Animal Reproduction Science, 126: 61-69. DOI: https:// 10.1016/j.anireprosci.2011.04.012. Epub 2011 Apr 29.

Leury BJ, Murray PJ and Rowe JB (1990). Effect of nutrition on the response in ovulation rate in Merino ewes following Short-term lupin supplementation and insulin administration. Australian Journal of Agricultural Research, 41:751-759. DOI: https://doi.org/10.1071/AR9900751

Marzouk KM, El Zanouny AI and Kaoud MA (2018). Flushing vs. Hormonal treatment, which better improve the reproductive performance of Ossimi ewes? Egyptian Journal of Sheep and Goat Sciences, 13(2):18-25. DOI: https://10.21608/ejsgs.2018.26245

Mekuriaw Z, Assefa H, Tegegne A and Muluneh D (2016). Estrus response and fertility of Menz and crossbred ewes to single prostaglandin injection protocol. Tropical animal health and production, 48:53-57. DOI: https://10.1007/s11250-015-0919-z 
Menchaca A, Miller V, Gil J, Laca M and Rubianes E (2004). Prostaglandin $F_{2} \alpha$ treatment associated with timed artificial insemination in ewes. Reproduction Domestic Animal, 39:352-355. DOI: https://10.1111/j.1439-0531.2004.00527.x

Molle G, Branca A, Ligios S, Sitzia M, Casu S, Landau S and Zoref Z (1995). Effect of grazing background and flushing supplementation on reproductive performance in Sarda ewes. Small Ruminant Research, 17:245-254. DOI: https://10.1016/0921-4488(95)00691-D

Naderipour H, Yadi J, Shad AGK and Sirjani MA (2012). The effects of three methods of synchronization on estrus induction and hormonal profile in Kalkuhi ewes: A comparison study. African Journal of Biotechnology, 11:530-533. DOI: http://10.5897/AJB11.2718

Naqvi SMK, Gulyani R and Mittal JP (1997). Estrus synchronization response in Kheri ewes treated with prostaglandin $F_{2} \alpha$. Indian Journal of Animal Science, 68(6):564-565.

Navanukraw C, Khanthusaeng V, Kraisoon A, and Uriyapongson, S (2014). Estrous and Ovulatory Responses Following Cervical Artificial Insemination in Thai-Native Goats Given a New or Once-Used Controlled Internal Drug Release with Human Chorionic Gonadotropin. Tropical Animal Health and Production, 46(8):1441-1446. DOI: https://10.14456/tijsat.2016.17

Ozturkler Y, Colak A, Baykal A and Guven B (2003). Combined effect of a prostaglandin analogue and a progestestagen treatment for 5days on oestrus synchronization in Tushin ewes. Indian Veterinary Journal, 80:917-920.

Ray B, Dehuri PK, Mishra SK, Swain RK, Mohanty DN and Dash SK (2012). Effect of supplementation of concentrate on reproductive performance of grazing Ganjam goat in its native tract. The Indian journal of animal sciences, 82:419-422.

Ribeiro ELA, Silva LDF, Mizubuti IY, Rocha MA, Silva AP, Mori RM, Ferreira DOL and Casimiro TR (2002). Desempenho produtivo de ovelhas acasaladas no verão e no outono recebendo ou não suplementação alimentar durante o acasalamento. Semina Ciênc Agrar, 23:35-44. DOI: https://10.5433/1679-0359.2002v23n1p35

Safranski TJ, Lamberson WR and Keisler DH (1992). Use of melengesterol acetate and gonadotropins to induce fertile estrus in seasonally anestrous ewes. Journal of Animal Science, 70:2935-2941. DOI: https://10.2527/1992.70102935x

SAS (2004). Statistical analysis system User's Guide. Release 9.1. SAS institute, Cary, North Carolina.

Snyman MA (2010). Influence of body weight, age and management system on reproduction of South African Angora goat does. South African Journal of Animal Science, 40:410:41 DOI: http://10.4314/sajas.v40i1.54129

Sormunen-Cristian R and Jauhiainen L (2002). Effect of nutritional flushing on the productivity of Finnish Landrace ewes. Small Ruminant Research, 43:75-83. DOI: https://10.1016/S0921-4488(01)00262-0

Sozbilir NB, Marasli S, Ozturkler Y and Ucar O (2006). Effect of double injection of $\mathrm{PGF}_{2} \alpha$ at different intervals on some reproductive traits in Tuj ewes. Turkey journal of Veterinary and Animal Science, 30:207-211.

Waheeb RS, El-amrawi GA, Metwelly KK and El-sabbagh AM (2017). Synchronization of estrus in field conditions using progestagen sponge, GnRH, and PGF2 $\alpha$ in Barki ewes during breeding season. Alexandria Veterinary Science, 54(2): 1-4. DOI: https://10.5455/ajvs.273830

Wildeus S, Traugott KT and Fugle JR (1989). Effects of pre-breeding supplementation on body weight and reproductive characteristics in multiparous and nulliparous St Croix ewes. Journal of Animal Science, 67: 64.

Yavuzer U, Zonturlu A and Aral F (2010). Effect of Recombinant Follicle Stimulating Hormone (rFSH) on Some Fertility Parameters in Awassi Ewes Synchronized with $\mathrm{PGF}_{2}$ in the Breeding Season. Ankara Üniversitesi Veteriner Fakültesi Dergisi, 57: 241-245. DOI: https://10.1501/Vetfak_0000002432

Yildiz S, Uzun M, Kaya M, Ucar O and Çenesiz M (2004). Effects of rams and luteal or follicular phase ewes on preovulatory LH surge characteristics in ewes. Turkish Journal of Veterinary and Animal Science, 28:669-673.

Yoder RA, Hudgens RE, Perry TW, Johnson KD and Deikman MA (1990). Growth and reproductive performance of ewe lambs fed corn or soybean meal while grazing pasture. Journal of Animal Science, 68:21-27. DOI: https://10.2527/1990.68121x

Zarkawi M (2000). The evaluation of two doses of prostaglandin $F_{2} \alpha$ analogue, prosolvin, for oestrous synchronization of Syrian Awassi ewes. New Zealand Journal of Agricultural Research, 43:509-514. DOI: https://10.1080/00288233.2000.9513447

Zhang C, Yang L and Shen Z (2008). Variance components and genetic parameters for weight and size at birth in the Boer goat. Livestock Science, 115:73-79. DOI: https://10.1016/j.livsci.2007.06.008

Zohara BF, Azizunnesa Islam F, Alam GS and Bari FY (2014). Comparison of estrus synchronization by PGF $_{2} \alpha$ and progestagen sponge with PMSG in indigenous ewes in Bangladesh. GSTF International Journal of Veterinary Science, (1(1):27-37. Available at: http://dl6.globalstf.org/index.php/JVet/article/view/1330/1248

Zonturlu AK, Aral F, Ozyurtlu N and Yavuzer U (2008). Synchronization of estrus using FGA and CIDR intra vaginal pessaries during the transition period in Awassi ewes. Journal of Animal and Veterinary Advances, 7(9):1093-1096. Available at: http://medwelljournals.com/abstract/?doi=javaa.2008.1093.1096 